церковные традиции, и религиозно-мистический смысл «русской веры» имели определяющий смысл. По Лескову, русская православная церковь превратилась в фальсификатора заповедей Того, Кого писатель именовал «повешенным на кресте праведником» [Leskov 1958: 2, 529]. Поэтому заслуживают обличения ее «тысячи пошлостей и подлостей».

Лесков, который, начиная с 1860-х гг. и до последних дней так много писал о религиозной жизни русского народа, хорошо знал мир старообрядцев и сектантов, сам искал «истинную веру». Но к 1880-м гг. он фактически отвернулся от православия («у нас византиизм, а не христианство») и пришел к проповеди внеконфессионального христианства («Мелочи архиерейской жизни», «Синодальные персоны», «Полунощники»). Лесков все более убеждал себя в том, что народ стремится приложить евангельское учение к практической жизни, все более приближаясь к идеям Л.Н. Толстого.

\title{
REFERENCES:
}

1. Annenskiy, L. A. (1988) Neslomlennyy. Povest' o Leskove / Tri yeretika. Moscow, pp.229-351.

2. Dostoyevskiy, F.M. (1972-1989). Poln. sobr. soch.: V 30 t. Leningrad.

3. Leskov, N. S. (1874). Ocherki iz istorii Tambovskogo kraya. Grazhdanin, vol. 4, 26 yanvarya.

4. Leskov, N. S. (1958). Sobr. Soch.: V 11 t. Moscow.

5. Smolyakova, M. S. (2007). N. S. Leskov. Ot problemy «narodnosti» k ideye «pravednichestva». Vesnik MDU imya A.A. Kulyashova, vol. 2-3 (27), pp. 121-125.

Шарапова A. Національний інститут адукаиії (Республіка Білорусь)

Sharapava A. Institution National Institute of Education (Republic of Belarus)
АЎТАБІЯГРАФІЧНЫЯ ТВОРЫ АЛЕНЫ ВАСІЛЕВІЧ 'ПАЧАКАЙ, ЗАТРЫМАЙСЯ..." І ІВАНА НАВУМЕНКІ “ДЗЯЦНСТВА. ПАДЛЕТАК. ЮНАЦТВА”: АСАБЛІВАСЦІ СТВАРЭННЯ СЭНСУ I СТРУКТУРЫ 


\section{AUTOBIOGRAPHICAL WORKS BY ALENA VASILEVICH 'WAIT, STAY AND ...' AND IVAN NAVUMENKA 'CHILDHOOD. TEENAGER. YOUTH’: FEATURES OF CREATING MEANING AND STRUCTURE}

У статті розглядаються смислові та структурні особливості текстів автобіографічного характеру на прикладі творів білоруських авторів Олени Василевич та Івана Науменко. Стверджується, щуо згадані твори, входячи в контекст документально-художньої літератури, мають давні істориколітературні традииії, відтворюють епоху і особистість в ній. Твори Василевич та Науменко мають загальні визначальні ознаки: в змістовному плані - насиченість семантичної елементами зі значенням “пам'ять”, “час”, “илях”; увагу до певних періодів життя дитини; в формальному плані - варіації в вираженні форми особи оповідача; використання різних форм часу з переважанням нинішнього; ліризм $i$ суб'єктивізм розповіді.

Ключові слова: автобіографія, сенс, структура, автор конкретний і абстрактний, наратор, нараційния плани.

The paper deals with semantic and structural features of texts of autobiographical nature on the example of works of Belarusian authors Alena Vasilevich and Ivan Navumenka. It is stated that the mentioned pieces of work, entering the context of documentary literature, have long-standing historical and literary traditions, recreate the time period and the personality in it. The works by Vasilevich and Navumenka have common determining features: in terms of the content, the saturation with semantic elements with the meaning "memory", "time", "path of life"; attention to certain periods of a child's life; in terms of form - variations in the presentation of the form of the narrator's person; the use of various forms of time with a predominance of the present; lyricism and subjectivity of the narration. However, each of the texts has its own original features, which is explained by the peculiarities of the authors' style, as well as the time when the works were written.

Key words: autobiography, meaning, structure, real and implied author, narrator, narrative plans.

Пастаноўка праблемы. Беларуская проза характарызуецца актыўным засваеннем твораў аўтабіяграфічнага і дакументальнага характару. Такая 3'ява тлумачыцца не толькі кан'юнктурай, што ўлічвае цікавасць чытачоў 
да невядомых ці малавядомых фактаў найперш асабістага жыцця выбітных асоб, але і логікай развіцця літаратурнага працэсу, і спецыфікай саміх мастацкіх тэкстаў. Аўтабіяграфія, як ніякі іншы жанр, паказвае працэс фарміравання, самавыхавання асобы ў варунках лёсу, што робіць падобны твор вельмі важным у кантэксце дзіцячай літаратуры, у працэсе фарміравання чалавека і грамадзяніна [Sharapava 2016: 55].

Аўтабіяграфічныя творы Васілевіч (н. у 1922) і Навуменкі (н. у 1925) ахопліваюць практычна адзін і той жа перыяд XX ст. і даюць цэлую панараму складаных гістарычных падзей: ад першых гадоў пасля рэвалюцыі да Вялікай Айчыннай вайны ўключна. Гэтыя тэксты паказваюць: маладыя людзі ў пошуку ўласнага жыццёвага шляху, сутыкаюцца $з$ падобнымі, нават аднолькавымі жыццёвымі выпрабаваннямі, праблемамі, пытаннямі побытавага і экзістэнцыйнага характару. Важна, што вылучаныя для аналізу творы дазваляюць прасачыць пэўны этап развіцця жанру мастацкай аўтабіяграфіі аповесці ў айчыннай літаратуры, бо асобнае выданне тэтралогіі Васілевіч датуецца 1972 г., а трылогія Навуменкі - 1997 г.

Аналіз апошніх дасягненняў. У сучасных літаратуразнаўчых даследаваннях айчынных (В.Стральцова, Т.Тарасава, Н.Сівакова і інш.) і замежных (Г.Раманава, Н.Ніколіна, А.Пагодзіна, М.Медарыч, А.Златар і інш.) аўтараў усё часцей ідзе гаворка пра вылучэнне аўтабіяграфіі ў асобны празаічны жанр, што адносіцца да такога міжродавага ўтварэння, як дакументальна-мастацкая (мемуарна-аўтабіяграфічная, мемуарыстычная) літаратура.

Названае ўтварэнне, вядомае яшчэ з Антычных часоў, на працягу свайго доўгага развіцця сфарміравала разгалінаваную жанравую сістэму. Гэта аўтабіяграфія, споведзь, мемуары, дзённікі і іншыя жанравыя ўтварэнні, межы паміж якімі дастаткова ўмоўныя і рухомыя. Уласна літаратурная аўтабіяграфія - гэта аб’ёмны празаічны твор, у якім аўтар рэтраспекцыйна адлюстроўвае падзеі ўласнага жыцця. “Автобиография - это повествовательный текст с ретроспективной установкой, в котором реальная личность рассказывает о собственном бытии, и притом ударение ставит на свою личную жизнь, собственно историю становления своей личности" [Medarich 1998: 7]. У аўтабіяграфічным жанры “<..> автор теряет иенностную точку вненаходимости героя" 
[Bakhtin 1979: 273], г.зн. у гэтым жанры аўтар і апавядальнік тоесныя. Блізкасць названых камунікацыйных інстанцый надае тэксту суб'ектыўнасць, робіць яго люстрам канкрэтнай гістарычнай эпохі.

“Автобиографические произведения неоднородны. Развитие жанра, его взаимодействие с воспоминаниями и мемуарами, наконеи, проникновение этой жанровой формы в художественную литературу привели $к$ возникновению разветленной внутрижанровой системы, в которую входят: 1) собственно автобиографии <...>; 2) автобиографические тексты, включающие одновременно развернутые воспоминания о прошлом, связанных с ним реалиях, лицах и т.n.; 3) автобиографии и воспоминания, тяготеющие $\kappa$ беллетризованной форме <...>; 4) художественные произведения, использующие жанровую форму автобиографии и опираюшиеся на реальные факты жизни автора (см., например, повесть С.Т. Аксакова «Детские годь Багрова-внука», роман И.А. Бунина «Жизнь Арсеньева», тетралогию Б.А. Зайцева «Путешествие Глеба» и др.)” [Nikolina 2011: 12]. У кантэксце чацвёртай групы аўтабіяграфічных твораў паказальнымі ў беларускай літаратуры з'яўляюцца “Камароўская хроніка" Максіма Гарэцкага, “у дрымучых лясах” Змітрака Бядулі, “Шлях 3 цемры” Янкі Маўра, “Пачакай, затрымайся...” Алены Васілевіч, “Дзяцінства. Падлетак. Юнацтва” Івана Навуменкі, “Муштук і папка” Янкі Брыля і інш.

Мэта даследавання. Ахарактарызаваць структурна-сэнсавыя асаблівасці твораў Васілевіч і Навуменкі пры адлюстраванні такіх спецыфічных элементаў аўтабіяграфічнай літаратуры, як 1) дзяцінства, падлеткавы ўзрост, юнацтва, 2) прататыпнай гістарычнай асновы. Задачы даследавання: вылучыць традыцыйныя структарна-сэнсавыя элементы, жанравыя асаблівасці аўтабіяграфічных тэкстаў; паказаць наватарства Васілевіч i Навуменкі пры стварэнні імі аўтабіяграфічнай літаратуры.

Для аўтабіяграфічных твораў характэрна наяўнасць двух часавых планаў: першасны план (як правіла, ён зведзены да мінімуму) сучасны таму апавядальніку, які непасрэдна стварае тэкст; другасны план (галоўны) максімальна выяўлены, гэта план мінулага, пра які вязецца аповед. Менавіта наяўнасць двух нарацыйных фокусаў i з'яўляецца сэнса- i формаўтваральным цэнтрам аўтабіяграфічнага твора. Згаданыя 
нарацыйныя планы дазваляюць ствараць у тэксце дыялог паміж апавядальнікамі розных узроўняў, што набліжаецца да своеасаблівага ўнутранага дыялогу ў свядомасці абстрактнага аўтара: “Кожны раз, калі я азіраюся ў тую, ияпер ужо дайнюю далячьнь, кожны раз я пытаю ў сябе: “Няўжо гэта там, за тылм засмужаным ружовым туманам ранкам, жывой галінкай зелянееш ты сама? <...> // [Знак // тут і далей у тэксце выкарыстоўваецца для абазначэння абзацаў у цытатах]. I ияяпер, калі між намі лягла такая неабсяжная прастора часу $і$ ўзросту, калі лягло столькі камення на той дарозе, якая нас развяла $i$ раз'яднала, я пытаюся, дзівячыся і спадзеючыся: // - Тая даўняя з таго далёку ТЬІ - гэта Я? I Я цяяерашняя - гэта ТЫ таксама? // I я заву иябе са смуткам і надзеяй адтуль, з тае раніцы: // - Пачакай, затрьлмайся...” [Vasilevich 1994: 3].

Блізкасць аўтара 3 апавядальнікам праяўляецца ў паказальнай інфармаванасці пра падзеі, дакладным паказам унутранага жыцця i перажыванняў галоўнага героя: “У хац̧е трое хлопц̧аў, ядуц̧ь на поўную шчаку так, што дзвюх, часам нават трох буханак хлеба не хапае. Зарплату між тылм прыносіць адзін бацька. Зарплата старшага стрэлачніка вядомая - сто дващџцаць шэсцьь рублёў. Ну, прырабатвае $з$ паўсотню бацька, часам прагрэсіўку палучыщъь. Маці бялізну старым жанчынам мыле. Вася за лета сотні пауттары заробіць. Але гэта дробязі. Грошай у асноўным хапае толькі на хлеб” [Navumenka 2008: 245-246]. Якраз у гэтым, адным 3 многіх эпізодаў, адлюстраваны канкрэтныя факты 3 біяграфіі пісьменніка Навуменкі, пацверджаныя дакументамі, уласнымі ўспамінамі і ўспамінамі сваякоў.

Аўтабіяграфічныя творы з'яўляюцца аб'ектыўнай крыніцай звестак пра пэўны час і прастору, бо ў іх узнаўляецца побыт, карціны працы і святаў, гістарычныя аспекты, маўленчыя асаблівасці: “Мая мясцовасиьь Прылняпроўска-Прыпяикае Палессе з гарадамі Рэчыцуа, Мазыр, Пінск, Брэст, у акупацьюю была далучана да Украіны. Для насельніцтвва гэта не мела ніякага значэння. Вёскі немиьы палілі гэтак жа, як $і$ ва ўсіх другіх мясцінах, дзе былі партызаны, вывозілі моладзь на работу у Германію. Тут, у Роўне, сядзеў гайляйтар Украіны Эрых Кох, а уу ровенскім банку выпускаліся ўкраінскія карбованцы. На карбованцах усе надпісы былі 
зроблены па-нямецку і толькі на другой палавіне банкноты, маленькімі літаркамі,-па-ўкраінску" [Navumenka 2008: 478-479]. "Можа, паглядзімо [тут і далей падкрэслена намі - А.Ш.] на ix, ды мы і самі будзем ставіць...” [Vasilevich 1994: 68], “От любата вам, дзяўкі, на печьы! - гукнула на печ цётка Фядора, расшпільваючь здубянельмі пальцамі паўшубак” [Vasilevich 1994: 309], "Не уттаўкуса ніяк адна з гэтаю сваёю плоймаю. Не накармлюса ніяк” [Vasilevich 1994: 310].

Часава-прасторавая, а таксама ацэначная маркіраванасць выразна праяўляецца нават у назвах аўтабіяграфічных тэкстаў. Напрыклад, значэнне часу ўвасабляе назва таго ці іншага адрэзку жыцця: Навуменка “Дзяцінства. Падлетак. Юнацтва”, семантычны кампанент ацэнкі праяўляецца як у агульнай назве тэтралогіі Васілевіч, так і назвах асобных яе частак "Расці, Ганька", “Доля знойдзе цябе”, “Новы свет”. Цікава, што і падзагаловак твора "Пачакай, затрымайся..." Васілевіч - “Крыху выдуманае апавяданне" - таксама ўтрымлівае пэўную аўтарскую ацэнку жанравай формы. Дарэчы, элемент прасторы, дзе будзе ўтрымлівацца канцэпцыйны вобраз “шляху жыцця” можна ўбачыць ў назве аповесці Янкі Маура "Шлях $з$ цемры”; прасторавая пазіцыя апавядальніка адлюстравана i ў загалоўку твора Змітрака Бядулі “У дрымучых лясах”.

Любая аўтабіяграфія з’яўляецца даведачным матэрыялам пра жыццё пэўнага героя тэксту. Таму абавязковымі элементамі такіх твораў будуць наступныя паняцці: нараджэнне, сям'я персанажа, занятак бацькоў, вучоба, захапленні, сталенне, працяг адукацыі і г.д.: “Так, ёсиь на свеце і непрыемнасиі, але Вася на іх не зважае. Не надта добра жывуць між сабой дзед Піліп $і$ њюу бачька. Дзед гневаециа на сына за тое, што не эмшу жыць на хутары, кінууся на чыгунку. <..> Але бацьку, відаць, больш, чым хутар $i$ зямля, вабіла чыгунка. Затое папаездзіў баиька па свеце” [Navumenka 2008: 15].

Аўтабіяграфічныя творы вызначаюцца маркіраванасцю тэксту словамі са значэннем “памяць”, “успамін”, “мінулае”. Цікава, што часам успамін не з'яўляецца паслядоўным. Чалавечая свядомасць 3 ранняга дзяцінства ўзгадвае самае яркае і выразнае: "3 якога часу Вася сябе памятае. <..> Яму здаеииа, ён не нараджаўся, а быў на свеце заўсёды”" 
[Navumenka 2008: 11]. “3 паасобных пробліскаў памяці, якія успьххаюць, нібы маланкі у цемені начы, вымалёўваециа кариіна ранейшага Васевага жыция” [Navumenka 2008: 13].

Важнае значэнне ў аўтабіяграфічных творах набывае ацэначнарэфлексійны кампанент, у якім спалучаюцца планы апавядальнікаў абодвух узроўняў. Падобныя элементы ў тэксце насычаны словамі, якія характарызуюць эмацыйны стан, інтэлектуальныя здольнасці, эмпаційныя якасці не толькі галоўнага героя, але і іншых персанажаў тэксту: “Васілю робіџиа горка. Ён лічыў, што добра ўладкаваўся: жыве у баџькавай хаце, мае няхай невялікі заробак і вучыщиа ў школе. Але ў параўнанні з Алесяй ён лайдак і няздара. Прыгожае, шустрае дзеуччанё не пабаялася адарвачиа ад баиькавай хаты, паехала у невядомую даль і ямчэ у тэхнікум уладкавалася ” [Navumenka 2008: 372]. У падобным кантэксце вельмі паказальныя старонкі, што адлюстроўваюць трагедыю Ганькі Гурновіч - смерць маці. Дзяўчынка заўсёды адчувае яе прысутнасць. Напрыклад, яна наведвае могілкі і, нібы з жывой, гаворыць з маці: “А я ўжо у школу пайду заўтра, кажа яна мачі, прыбіраючы яе магілку кветкамі. - Я ўжо і торбачку склала сваю, і сукенку, і хустку падрыхтавала" [Vasilevich 1994: 116]. Хоць маці маўчыць, але Ганька добра ведае, што сказала б ёй матуля, і чытачы нібы чуюць тыя словы (так наратар мадэлюе гэты дыялог): “Глядзі ж, дачушка, старайся, добра вучься. Не лянуйся, глядзі. Настаўніка слухайся $і$ з дзецьмі сябруй” [Vasilevich 1994: 116]. Часам здаецца ёй, што “маџі ідзе услед за Ганькай лёгкім нячутным крокам. I Ганьщы зноў жыщь добра $і$ лёгка" [Vasilevich 1994: 197].

У абраных для аналізу аўтабіяграфічных творах ключавое значэнне набываюць граматычныя формы цяперашняга часу, якія выцясняюць формы прошлага часу. Мінулае нібыта ствараецца на вачах у рэцыпіента, а апавядальнік пры гэтым перажывае яго яшчэ раз і таму здольны найбольш дакладна ўзнавіць эмацыйны фон свайго дзяцінства і маладосці. Можна параўнаць: "Ганька з кожным днём адчувае, як жыциё яе, нібыта тая лодка, што выбілася з твані на вольную ваду, шыбуе па гэтай лёгкай вадзе наперад” [Vasilevich 1994: 219]. “Школьная навука ідзе звычайна, размерана, і тут Вася не падкачае. Яму лёгка, добра вучыциа” [Navumenka 2008: 226]. "Кіно Васю захапляе. Трохі менш, чым птушкі, кнігі, але захапляе” [Navumenka 2008: 229]. 
Тыпы аповеду ў аўтабіяграфічных тэкстах выкарыстоўваюцца дастаткова стандартныя - ад 1-й асобы і ад 3-й асобы. Паказальна, што творы, абраныя для аналізу, выкарыстоўваюць абодва варыянты нарацыі: і ад 1-й асобы, і ад 3-й. Аповесці тэтралогіі А. Васілевіч напісаны ў рознай манеры: першая дзве ад імя імпліцытнага апавядальніка, а дзве апошнія ад “Я” самой Ганькі. Першыя дзве аповесці I. Навуменкі напісаны ад 3-й асобы, а апошняя - ад 1-й. Ствараецца ўражанне, што пісьменнікі “баяцца" даць самастойнасць сваім пакуль яшчэ маленькім персанажам. Апавядальнік нібыта апранае маску дзіцяці, і праз гэта аповеду надаецца свежасць дзіцячага светаўспрыняцц: “На стол кладзещиа лыжка, якой ніхто не карыстаециа. Рэшткі яды, міскі, талеркі так і застающиа на стале. Ноччу пасядуць за стол дзяды... // Дзіууна яны ядуць: усё на стале як было, так $і$ засталося. Але дзядой усё адно “кормяць". Інакш яны засярдуюиь $i$ могуцьь наклікаць бяду" [Navumenka 2008: 29] або "Ганьцы на печы гэтыл Салаўкі і Мурманск уяўляючиа не інакш як нейкай замарожанай снежнай пустыняй, з якой, калі чалавек трапіў туды, жывым ужо ніколі не выйдзе. Няма сонца, няма свету, няма зямлі пад нагамі. (Калі няма жыта, значыць, няма $і$ зямлі.) Кругом толькі ледзяная ноч...” [Vasilevich 1994: 146]. Пры гэтым аповед ад 3-й асобы напоўнены дакладнымі імёнамі, падзеямі і фактамі, а таксама ў ім, у лірычных адступленнях, сустракаюцца пераходы да 1-й асобы: “...У вас яна таксама ёсиь - гэта чароўная краіна з нетутэйшай назвай - Ідылія. Праўда, у вас яна свая. У мяне свая. // Хочаце ведаџь, дзе яна знаходзіциа? // 3 гэтымм, праўда, крыху ияжэй. Справа ў тым, што дзівакі, якія складаючь геаграфічныя карты, чамусьиі заўсёды забываюиь маю Ідылію нанесиі на карту. // Але нічога. Я раскажу вам пра яе без карты”" [Vasilevich 1994: 6]. Дадзены прыклад адлюстроўвае яшчэ адну спецыфічную асаблівасць аўтабіяграфічнага жанру - прамы зварот да імпліцытнага нарататара аповеду.

Такім чынам, аналіз аўтабіяграфічных твораў А. Васілевіч і І. Навуменкі дазваляе прыйсці да наступных высноў.

1. Дакументальныя, біяграфічныя і аўтабіяграфічныя творы маюць даўнія літаратурна-гістарычныя традыцыі, з'яўляюцца своеасаблівым 
люстэркам эпохі. Акрамя дакладнасці ўзнаўлення разнастайных падзей эпохі такія творы звяртаюцца найперш да адлюстравання розных праяў духоўнага фарміравання і сталення асобы, што робіць падобныя тэксты актуальнымі ў кантэксце выхавання маладога пакалення.

2. Аўтабіяграфічныя творы маюць наступныя агульныя вызначальныя прыкметы: у змястоўным плане - насычанасць семантычнымі элементамі са значэннем “памяць”, “час”, “шлях”; увага да пэўных перыядаў жыцця дзіцяці; у фармальным плане - варыяцы ў выражэнні формы асобы апавядальніка; выкарыстанне розных формаў часу 3 перавагай цяперашняга; лірызм і суб'ектывізм аповеду.

3. Аўтабіяграфічны твор А. Васілевіч, а таксама творы Янкі Маўра, Змітрака Бядулі і інш., падрыхтавалі глебу для развіцця падобнага жанру ў айчыннай літаратуры, вызначыўшы найбольш традыцыйныя яе прыкметы.

4. I. Навуменка па-наватарску ўзбагаціў дакументальна-аўтабіяграфічны жанр. Пісьменнік імкнецца да аб'ектывацы аповеду, ведучы яго адстаронена. Аўтар імкнецца пазбягаць часавых лакун, стварае аповед, арыентуючыся на логіку гістарычных падзей, а не на плынь уласнай свядомасці. Выкарыстоўваючы лірычны па сваёй сутнасці жанр аповесці, I. Навуменка здолеў стварыць маштабнае палатно эпохі.

\section{REFERENCES}

1. Bakhtin, M.M. (1979) Estetika slovesnogo tvorchestva. Moskva: Iskusstvo, 424 s. (in Rus.).

2. Vasilevich, A. (1994) Pachakai, zatrymaisia...: apovestci. Minsk: Junatctva, 526 s. (in Bel.).

3. Medarich, M. (1998) Avtobiografiia / avtobiografizm. Avtointerpretatciia: sb. statei; pod redakcijej A.B.Muratova, L.A.Iezuitovoi. Sankt-Peterburg: Izdatelstvo SPbGU, 5-32. (in Rus.).

4. Navumenka, I.Ja. (2008) Dziatcinstva. Padletak. Junatctva. Minsk: Mastackaja litaratura, 622 s. (in Bel.).

5. Nikolina, N.A. (2011) Poetika russkoi avtobiograficheskoi prozy. Moskva: "FLINTA" "Nauka", 424 s. (in Rus.).

6. Sharapava, A.V. (2016) Vyvuchenne tvorchastci Aleny Vasilevich u kantekstce vuchebnai dystcypliny "Susvetnaia i aichynnaia dzitciachaia litaratura": tearetychnazhanravy aspect. Kuliashouskiia chytanni: materyialy Mizhnarodnai navukovapraktychnai kanferentcyi, 21 krasavika 2016 g., / pad agulnaj redakcyjaj S.E.Somava. Magileu: MDU imja A.A.Kuljashova, 53-59. (in Bel.). 